\title{
The IT Way of Loafing in Class: Extending the Theory of Planned Behavior (TPB) to Understand Students' Cyberslacking Intentions
}

\author{
Nripendra P. Rana \\ School of Management \\ University of Bradford, UK \\ Email:nrananp@gmail.com \\ Emma Slade \\ Department of Management \\ University of Bristol \\ Queen's Avenue, Bristol, UK \\ Email: emma.slade@bristol.ac.uk \\ Sebastian Kitching \\ School of Management \\ Swansea University \\ Fabian Way, Swansea, SA1 8EN, UK \\ Email: s.w.kitching@swansea.ac.uk \\ Yogesh K. Dwivedi* \\ School of Management \\ Swansea University \\ Fabian Way, Swansea, SA1 8EN, UK \\ Email: ykdwivedi@gmail.com
}

\begin{abstract}
Internet-enabled technologies can facilitate students' learning, engagement, and productivity but they also present challenges by way of distraction. Cyberslacking is the use of internetenabled technologies by students in class for non-class related activities. This research attempts to understand the factors that influence students' cyberslacking intentions in class, through extending the Theory of Planned Behavior with lack of attention, apathy towards course material, distraction by others, perceived threat, and escapism. Quantitative data were collected $(\mathrm{n}=188)$ using a survey method with undergraduate and postgraduate students from a management school in a British university. All eight proposed hypotheses were found to be supported. The findings indicated that constructs such as lack of attention, apathy towards course material, and distraction by others are significant predictors of attitude. Further, attitude, subjective norm, perceived behavioral control, perceived threat, and escapism were found to significantly influence students' cyberslacking intentions.
\end{abstract}

Keywords: cyberslacking, student engagement, higher education, teaching and learning, TPB

\section{Introduction}

The use of technology and online instruction as part of teaching is becoming increasingly prevalent in educational institutions (McBride et al., 2013). For students, digital technologies 
such as laptops, tablets and smartphones are commonly found in classrooms to access course materials and educational videos, to take online tests, and contribute in class (Galluch and Thatcher, 2011; Ragan et al., 2014; Taneja et al., 2015). For instructors, Internet-enabled tools are used to update course materials, mark coursework, provide feedback, and communicate with students (Galluch and Thatcher, 2011; Gerow et al., 2010). Although the use of Internet-enabled digital technologies has been found to improve students' attentiveness and engagement in the class (Samson, 2010), anecdotal evidence suggests that maladaptive use of such technologies can divert students to engage in activities that have little or no relation to the task at hand (Fried, 2008; Ragan et al., 2014; Ravizza et al., 2014).

Cyberslacking (also referred to as cyberloafing, non-work-related computing, cyber deviance, personal use at work, Internet abuse, workplace Internet leisure browsing, junk computing, non-classroom related activities, etc.) is the use of Internet and mobile technology during work/class hours for non-work/class related purposes (Rana et al., 2016c; Vitak et al., 2011). Students occupying themselves with other activities, such as browsing social media, checking email, reading news, instant messaging, and photo sharing through smartphones, rather than with assigned work in class is a common occurrence (Keser, 2016) but if instructors want a vibrant and productive classroom full of attentive and engaged students, they must find ways to prevent students' adverse use of technology (Sana et al., 2013; Taneja et al., 2015). Given the significance, sensitivity, and criticality of this issue, it is important for researchers to explore students' cyberslacking behavior from a variety of perspectives. A key motivation to undertake this research is to raise awareness of the factors that influence learners' cyberslacking attitude and behavior. The key research questions to be answered by this study are:

[1] What are the key factors that influence students' cyberslacking intention?

[2] Which of these factors have the strongest effects on students' cyberslacking intention?

Through answering these questions, the research can provide valuable insight for instructors regarding how to minimise students' cyberslacking in class with the aim of engaging students more in class-related activities.

The remainder of the paper is structured as follows. The next section introduces and reviews cyberslacking literature related to education. The subsequent section details the research model, which is underpinned by the Theory of Planned Behavior (TPB) and extended with lack of attention, apathy towards course material, distraction by others, perceived threat, and escapism. After the methodology used for collecting data and validating the proposed research model is explained, the findings from structural equation modelling are detailed. The penultimate section discusses the results in light of existing literature, and implications for theory, practice and technology enhanced learning are offered. Finally, the paper is concluded and consideration is given to limitations and future research.

\section{Literature Background}

Literature on cyberslacking can be divided into cyberslacking behavior of students (e.g. Baturay and Toker, 2015; Galluch and Thatcher, 2006; Galluch and Thatcher, 2011; Gerow et al., 2010; Giunchiglia et al., 2018; Gokcearslan et al., 2016; Keser et al., 2016; Mendoza et al., 2018; Rana et al., 2016c; Taneja et al., 2015; Yasar and Yudugul, 2013; Yilmaz and Yurdugul, 2018; Yilmaz et al., 2015) and cyberslacking behavior of employees or knowledge 
workers (e.g. Aghaz and Sheikh, 2016; Askew et al., 2014; Ince and Gul, 2011; McBride et al., 2013; O'Neill et al., 2014; Vitak et al., 2011). Only a handful of studies (e.g. Akbulut et al., 2016; Akbulut et al., 2017; Ugrin and Pearson, 2013) have included both student and nonstudent data.

For example, Galluch and Thatcher (2006) examined slacking with Internet technologies in a classroom environment. Rooted in the literature of social loafing, they developed a model with personal attributes influencing students' intention to cyberslack and its impact on the effective use of Internet technology. The findings suggested that personal innovativeness with information technology and multi-tasking with Internet applications contribute to cognitive absorption while cognitive absorption and subjective norms contributed to the intention to cyberslack. In a further study, Galluch and Thatcher (2011) developed a research model that explains faithful (i.e. appropriate) versus maladaptive (i.e. cyberslacking) use of Internet technologies in the classroom. The findings suggested that social norms and perceived threats affected cyberslacking intentions while effort expectancy, performance expectancy, and perceived opportunities contributed to appropriate use of IT. Gerow et al. (2010) also examined cyberslacking with Internet technologies in the classroom. They developed a research model linking external forces, such as social norms, distraction by other students' cyberslacking, and awareness of instructor monitoring, and internal forces, such as cognitive absorption with Internet technologies, and multitasking, to intention to cyberslack. Rana et al. (2016c) analysed 13 factors that could impact student cyberslacking behavior in the undergraduate business and management classroom. The results indicate that of 12 significant correlations, apathy towards course material, lack of attention, and subjective norm are positively and significantly correlated to students' attitude towards cyberslacking, whereas it is negatively linked to extrinsic motivation. Drawing upon an augmented version of TPB, social learning theory, and pedagogical literature, Taneja et al. (2015) investigated the factors influencing students' attitudes and intentions to use technology during class for non-class related purposes. The results indicated that student consumerism, escapism, lack of attention, cyberslacking anxiety, and distraction by others' cyberslacking behavior influenced students' attitude.

Existing research has found demographic differences in cyberslacking behaviors. Baturay and Toker (2015) examined the influence of demographics such as age, gender, Internet skills, Internet usage, and Internet experience on high school students' cyberloafing behaviors (such as personal business, news follow-up, and socialisation) in Turkey. The findings indicated that males, advanced-expert users, and more frequent Internet users' cyberloaf more than females, novice-intermediate users, and people who use the Internet less often. Yilmaz et al. (2015) identified the level of cyberloafing situations observed in courses in computer laboratories. The findings indicated that cyberloafing situations of the students are generally at a medium-level. Similar to Baturay and Toker (2015), it was also observed that cyberloafing levels significantly differ based on gender such that cyberloafing levels of male students are generally higher than those of female students.

Researchers have also explored the relationship between technology addiction and cyberslacking. Gokcearslan et al. (2016) examined the role of smartphone usage, selfregulation, general self-efficacy, and cyberloafing in smartphone addiction in Turkey. The results showed that both duration of smartphone usage and cyberloafing positively influenced smartphone addiction whereas the influence of self-regulation on smartphone addiction was 
negative and significant. Moreover, neither self-regulation nor general self-efficacy were found to influence cyberloafing. Keser et al. (2016) aimed to examine the relationship between preservice teachers' Internet addiction level and cyberloafing activities. The results indicated a moderate positive relationship between Internet addiction and individual and search cyberloafing and a minor positive relationship between Internet addiction and social cyberloafing. Yasar and Yudugul (2013) examined the relation between cyberloafing activities and cyberloafing behavior among Higher Education students in Turkey. The results indicated that while salvation, escape, and development behaviors of cyberloafing were not statistically significant, a significant relation between addiction behavior and the inclination to cyberloaf was found.

A handful of studies have explored individual cyberslacking behavior using both student and non-student data. Akbulut et al. (2016) developed a new and more comprehensive scale to address contemporary cyberslacking behaviors during lectures through literature review, expert panels, and observations. They found factors such as sharing, shopping, real-time updating, accessing online content, and gaming/gambling as a five-factor structure that explained $70.44 \%$ of the total variance. Akbulut et al. (2017) addressed the prevalence of cyberloafing and social desirability bias among students and jobholders in Turkey. The findings indicated that different types of cyberloafing had different dominance rates and that students surpassed employees, and males surpassed females, with regard to overall cyberloafing scores. However, employees surpassed students in terms of the impression management component of social desirability. Ugrin and Pearson (2013) provided a more comprehensive look at preventing cyberloafing. The authors collected data from students from two large public universities and employees from three firms in the USA. The results revealed that potential termination and likely detection effectively deterred abusive behaviors, such as viewing pornography and personal shopping, and potential termination, detection, and enforcement deterred non-abusive behaviors, such as personal emailing and social networking.

Studies that have focussed on employees and knowledge workers also offer useful insight. Aghaz and Sheikh (2016) explored the interrelationship of job burnout and cyberloafing. The findings indicated that both cyberloafing activities and behaviors have a significant impact on job burnout among knowledge workers. Askew et al. (2014) tested TPB as a model of cyberloafing and results from two studies unanimously supported the theory. The authors found evidence for cyberloafing as a withdrawal behavior and three predictors namely subjective descriptive norms, cyberloafing attitude, and perceived ability to hide cyberloafing predict cyberloafing. Results from Ince and Gul's (2011) study showed that academics have highly external locus of control and they objectify minor cyberslacking behaviors such as sending and receiving non-work emails, entering news websites, making holiday and travel reservations, and doing individual banking operations. McBride et al. (2013) examined cyberslacking behavior of graduate students from Arkansas University who were employed by school districts as classroom teachers. It was found that $51 \%$ of their university work was submitted during the time when they were employed in the school, i.e. when they were present in classrooms or during their time of preparation or supervision. Based on their findings, the authors recommended that professors do not allow interaction when students should be engaged in their school activities. Analysing the behavior of US working adults in the distributed working environment, O’Neill et al. (2014) found honesty and procrastination 
as powerful predictors of cyberslacking and engagement. Vitak et al. (2011) employed a nationally representative sample of US workers and tested the relationships between cyberslacking behaviors and a number of demographic and work-specific predictors. As with the student samples aforementioned, demographic differences were observed. The findings indicated that being younger, male, and a racial minority positively predicted cyberslacking variety and frequency.

Giunchiglia et al. (2018) proposed to overcome limitations of existing research linking learners' use of social media on smartphones and their academic performance through utilising time diaries to match reports of time usage with the actual logs of smartphone applications. Their findings confirmed that use of social media applications during undertaking any academic activities negatively influence students' academic performance. Mendoza et al. (2018) found that having cell phones in a short lecture has its largest impact on attention and learning 10-15 minutes into the lecture. Wu et al. (2018) examined the inclass and out-of-class cyberloafing activities of students in China and the results indicated cyberloafing as a harmful distraction in the classroom and supported a negative relationship between in-class cyberloafing and academic performance. Yilmaz and Yurdugul (2018) found that students' cyberloafing behavior is influenced by their psycho-social perceptions, attitudes and learning strategies. However, the results also revealed that the motivation for the course does not influence their cyberloafing behavior.

The summary of cyberslacking literature (Table 1) indicates that researchers have undertaken empirical work in a variety of contexts and settings to understand the factors that influence students' and non-students' cyberslacking behavior in their class or workplace. However, none of the existing research has used a comprehensive model to understand learners' behavior in the UK Higher Education system. In the UK context only Rana et al. (2016c) undertook a preliminary study on this topic and analysed the correlation between various factors influencing students' cyberslacking by considering a small sample of 21 students. Data were collected from only one class and little insight is offered about the sample other than proportion of males and females. With more than 2.34 million students enrolled at Higher Education institutions in the UK in 2017-2018 (Higher Education Statistics Agency, 2019), there is significant potential value in better understanding cyberslacking behavior in the UK context and comparing similarities and differences of findings with other studies, to improve learners' engagement in class-related activities.

Table 1. Summary of Cyberslacking Literature

\begin{tabular}{|l|l|l|l|}
\hline Context & Study & User type (Sample size) & Country \\
\hline Educational setting & Baturay and Toker (2015) & Students (282) & Turkey \\
\hline & Galluch and Thatcher (2006) & Students (128) & USA \\
\hline & Galluch and Thatcher (2011) & Students (311) & USA \\
\hline & Gerow et al. (2010) & Students (451) & USA \\
\hline & Giunchiglia et al. (2018) & Students (72) & Italy \\
\hline & Gokcearslan et al. (2016) & Students (598) & Turkey \\
\hline & Keser et al. (2016) & Students (139) & Turkey \\
\hline & Mendoza et al. (2018) & Students (160) & USA \\
\hline & Rana et al. (2016c) & Students (21) & UK \\
\hline & Sharma et al. (2016) & Students (215) & Oman \\
\hline & Taneja et al. (2015) & Students (267) & USA \\
\hline & Wu et al. (2018) & Students (1050) & China \\
\hline & Yasar and Yudugul (2013) & Students (215) & Turkey \\
\hline
\end{tabular}




\begin{tabular}{|l|l|l|l|}
\hline & Yilmaz and Yurdugul (2018) & Students (607) & Turkey \\
\hline & Yilmaz et al. (2015) & Students (288) & Turkey \\
\hline Workplace & Aghaz and Sheikh (2016) & Knowledge workers (298) & Iran \\
\hline & De Lara (2007) & Teachers (270) & Spain \\
\hline & Ince and Gul (2011) & Teaching staff (70) & Turkey \\
\hline & Kuschnaroff and Bayma (2014) & Employees (305) & Curitiba \\
\hline & Manrique de Lara et al. (2006) & Non-teaching staff (147) & Spain \\
\hline & Manrique de Lara et al. (2009) & Non-teaching staff (147) & Spain \\
\hline & McBride et al. (2013) & Professors (4) & USA \\
\hline & O'Neill et al. (2014) & Working adults (148) & USA \\
\hline & Vitak et al. (2011) & Workers (2134) & USA \\
\hline $\begin{array}{l}\text { Educational settings, } \\
\text { workplace and/or } \\
\text { general users }\end{array}$ & Akbulut et al. (2016) & $\begin{array}{l}\text { Teachers (33), Students } \\
\text { (479, 86, 471, 215), } \\
\text { Facebook users (515) }\end{array}$ & Turkey \\
\hline & Akbulut et al. (2017) & $\begin{array}{l}\text { Students (1339) and } \\
\text { jobholders (996) }\end{array}$ & Turkey \\
\hline & Askew et al. (2014) & $\begin{array}{l}\text { Student and non-student } \\
\text { employees (429) }\end{array}$ & $\begin{array}{l}\text { Mixed population } \\
\text { from USA, Asia, } \\
\text { Africa, Europe }\end{array}$ \\
\hline & Ugrin and Pearson (2013) & $\begin{array}{l}\text { Employees (81) and } \\
\text { students (69) }\end{array}$ & USA \\
\hline
\end{tabular}

\section{Conceptual Model and Hypotheses Development}

\subsection{Theoretical Background}

The Theory of Planned Behavior (TPB) has been widely used in various disciplines to explore behavior (Taneja et al., 2015). TPB is an extension of the Theory of Reasoned Action (TRA) (Fishbein and Ajzen, 1975), made necessary by the original model's limitations in dealing with behavior over which people have incomplete volitional control. In TPB, perceived behavioral control is theorised to be an additional determinant of intention and behavior (Ajzen, 1991). Ajzen (1991) presented a review of several studies that successfully used TPB to predict intention and behavior in a range of settings. The theory has been successfully implemented to explain individuals' acceptance and use of a number of different technologies (Shiau and Chau, 2016). In the context of the classroom, TPB is suitable as the basic proposed model as it focuses on theoretical constructs concerning individual motivational factors as determinants of likelihood of performing specific behaviors (Montano and Kasprzyk, 2015). Applying TPB to the cyberslacking context, the theory would postulate how the perceptions of referent others' cyberslacking behavior, attitude toward the use of Internet-enabled devices during the class, and perceived behavioral control toward cyberslacking contribute to cyberslacking intentions.

\subsection{Overview of the Proposed Research Model}

When used in new fields of study, TPB would often need to be adapted or expanded to suit the context and characteristics of the specific technology or system in place (Rana et al., 2016a; 2016c). TPB has been used in understanding student and employee cyberslacking behavior in prior research (Askew et al., 2014; Taneja et al., 2015). Whereas Askew et al. (2014) used TPB as a basic theoretical model to analyse student and non-student (e.g. employee) cyberloafing behavior, this study uses the core constructs of TPB and some other relevant external constructs (e.g. lack of attention, apathy towards course material, distracting others, escapism and perceived threats) to understand employees' cyberloafing behavior. Moreover, Taneja et al. (2015) presented a complex model of extended TPB with three layers 
of antecedents of intention to cyberslack. This study simplifies Taneja et al.'s model and considers only additional relevant constructs and relationships - such as apathy towards course material and attitude, and perceived threats and escapism with cyberslacking intentions - with the aim of creating a more parsimonious model explaining students' cyberslacking intentions. Given the aim of this study and the limitations of participants' selfreporting actual behavior, the dependent variable measured is cyberslacking intention.

\subsection{Hypotheses Development}

As depicted in Figure 1, a total of eight relationships were proposed between nine constructs. Three constructs, namely lack of attention, apathy towards course material, and distraction by others, are the antecedents of attitude whereas attitude, subjective norm, perceived threat, perceived behavioral control, and escapism are the antecedents of cyberslacking intention.

\subsubsection{Lack of attention}

Lack of attention refers to losing focus on what is being taught in the class. Students sometimes feel that the subject being taught to them is either not interesting or complex enough to understand, which makes them disinterested in the topic and results in lack of attention (Taneja et al., 2015). Lack of attention in class could also be due to other reasons such as instructor's monotonous and boring teaching style, students' preoccupation with outside interests, and instructor's lack of interactivity with students or control over the class. It is likely that students who lack attention in the classroom may be more inclined to form a positive opinion toward cyberslacking as they seek to engage their attention elsewhere. Therefore, we hypothesise:

H1: Lack of attention has a significant positive effect on students' attitude towards cyberslacking in the classroom.

\subsubsection{Apathy towards course material}

Apathy towards course material can be defined as a student's dislike or lack of interest toward the course material being taught in the classroom (Deed, 2011; Taneja et al., 2015). Apathy towards course material should be identified during the time students register for a course so that their likes/dislikes, strengths and weaknesses about that course could be judged well in advance. However, there are a variety of reasons students may select courses they are not interested in. For example, students who suffer anxiety about exams may select courses assessed via coursework, even if they are not interested in the course subject. Such courses are a cause for concern as students' lack of interest may lead them to develop apathy towards course material, and as a result they may divert their attention in class to cyberslacking activities. In other words, students' trait of lacking enthusiasm for or interest in their course material being taught in the classroom can form a favourable attitude toward cyberslacking. Therefore, we hypothesise:

H2: Students' apathy for course material has a significant positive effect on their attitude towards cyberslacking.

\subsubsection{Distraction by others}


Distraction by others in this context can be defined as the disturbance or disruption triggered to a student by other fellow students' constant use of Internet-enabled devices in class (Gerow et al., 2010; Taneja et al., 2015). It is difficult for any student to focus on their studies when other students sitting next to them are involved in cyberslacking activities (Gerow et al., 2015). Therefore, a student's attitude is negatively affected when they are distracted by others sitting next to them indulging in cyberslacking activities. Hence, the following hypothesis can be formulated from the above discussions:

H3: Distraction by other students through their cyberslacking activities negatively effects students' attitude toward cyberslacking.

\subsubsection{Attitude towards cyberslacking}

Attitude towards cyberslacking can be defined as an individual's positive or negative feelings about performing cyberslacking behavior (Davis et al., 1989; Fishbein and Ajzen, 1975). The role of attitude as a mediating variable and as an antecedent of behavioral intention has been consistently supported by prior literature on IS/IT adoption (Dwivedi et al., 2017a, 2017b; Rana et al., 2016a, 2017). Moreover, the inclusion of attitude in models of IS/IT acceptance is consistent with TRA (Fishbein and Ajzen, 1975), TPB (Ajzen, 1991), and the decomposedTPB (Taylor and Todd, 1995). In the context of this research, positive attitude towards cyberslacking would result in an individual's intentions to cyberslack. Hence:

H4: Students' attitude toward cyberslacking has a significant positive effect on their cyberslacking intention.

\subsubsection{Subjective norm}

Subjective norm can be defined as the degree to which a student perceives that their fellow friends believe that they should use laptops, smartphones, or any other Internet-enabled device during class for non-class related activities (Ajzen, 1991). Gerow et al. (2010) argue that if a student perceives that their peers want them to use a laptop or smartphone for nonclass related activities during the class then they will conform to that social pressure resulting in cyberslacking. A number of studies on IS/IT adoption have shown a significant positive impact of subjective norm on behavioral intention (Dwivedi et al., 2017b; Venkatesh et al., 2003). In this case, perceiving social pressure would encourage students' cyberslacking intentions. Therefore, we hypothesise:

H5: Subjective norm has a significant positive effect on students' cyberslacking intention.

\subsubsection{Perceived threat}

Perceived threat is defined as the perception that a punishment can result from the act of cyberslacking (Galluch and Thatcher, 2011). The prior research has established that the threat of likely loss can lead to significant negative influence on behavior. When a student perceives that they are likely to be punished if they are caught cyberslacking during class time, they would not intend to engage in such activities. This clearly indicates that perceived threat will have a negative impact on students' intentions to cyberslack. The prior empirical research (e.g. Galluch and Thatcher, 2011) on cyberslacking has also established this relationship. Therefore, we hypothesise:

H6: Perceived threat has a significant negative effect on students' cyberslacking intention. 


\subsubsection{Perceived behavioral control}

Perceived behavioral control can be defined "as the perceived ease or difficulty of performing the behavior" (Ajzen, 1991, p.188). Gerow et al. (2010) posit that behavioral control over cyberslacking is a relevant factor for understanding individuals' cyberslacking behavior. If a student feels that they have relatively easy opportunity to cyberslack in the classroom they would do it; however, if they think it would be difficult to cyberslack, for example due to constant monitoring by the teacher, they would be reluctant to perform such behavior (Taneja et al., 2015). Hence, a student's cyberslacking intention would be informed by the perceived ease or difficulty of performing such behavior in the classroom. Therefore, we hypothesise:

H7: Perceived behavioral control has a significant positive effect on students' cyberslacking intention.

\subsubsection{Escapism}

Escapism refers to a facet of playfulness that allows the student to temporarily get away from the class subject (Mathwick et al., 2001). Griffiths (2003) argued that online activities of interest carried out by an individual allow them to escape from the unpleasant veracities of real life. Diverting attention toward using Internet-enabled devices for non-class related activities could result from students' desire to escape boredom (Chan et al., 2009; Taneja et al., 2015). Therefore, it could be postulated that students' wanting to escape class activities will have greater intention to engage in cyberslacking (Taneja et al., 2015). Therefore, we hypothesise:

H8: Escapism has a significant positive effect on students' cyberslacking intention.

\section{Research Methodology}

\subsection{Questionnaire}

A survey-based approach was deemed most suitable to test the proposed hypotheses. All constructs were measured using a five-point Likert-scale anchored 1 'strongly disagree' to 5 'strongly agree'. Existing validated items were adopted for nine different constructs from prior studies (Galluch and Thatcher, 2011; Gerow et al., 2010; Taneja et al., 2015) and minor adaptations were made to fit the context (please see appendix). Eight demographic and contextual questions about Internet-enabled devices were also included.

\subsection{Sample and Data Collection}

The participants for this research belonged to a diverse cohort of students from both undergraduate and postgraduate taught programmes in the management school of a British university. This was done to have a better understanding of cyberslacking behavior by the students of management rather than a mixed cohort. The researchers taught numerous management courses at the same university at the time of data collection and so were able to distribute the questionnaire using a convenience sampling approach, adhering to the University's ethical approval guidelines. Students from four different classes were requested to voluntarily and anonymously complete a questionnaire. As participation was voluntary, not all students in the four different classes decided to take part. A total of 196 students across the four classes returned the paper-based questionnaire. It was found that eight of those returned were only partially completed and so were removed from further analysis. This resulted in a 
total number of 188 usable responses. Out of 188 valid responses, we also found that the questions related to 15 measures (from 12 students) for the different constructs remained unanswered. Missing Value Analysis offered by SPSS was used to automatically assign the appropriate values to those missing items.

\section{Results}

\subsection{Respondents' Demographic Profile}

The final data included 97 (51.6\%) male and 91 (48.4\%) female respondents. The majority of the students were from the UK (33.5\%) and China (50.5\%). A total of $97.3 \%$ of the students owned Internet-enabled phones or smartphones and $91 \%$ agreed that they use their smartphones or Internet-enabled phone to connect to the Internet in the classroom. Moreover, $58 \%$ of the students stated that they bring laptops or tablets to class.

\subsection{Descriptive Statistics}

Table 2 presents the mean, standard deviation, and Cronbach's alpha value for every construct used in the proposed research model. The mean values for all constructs except perceived behavioral control and perceived threat are less than 3. Lack of attention and apathy towards course material have the lowest means - 2.13 and 2.22 respectively - meaning that students tend to disagree with measurement items of these constructs, indicating that students are interested in their classes. The values of standard deviation for all constructs being less than 1 indicate that students largely have a consistent opinion about the questions asked. Reliability analysis of constructs was performed using Cronbach's alpha values. It is used to measure the reliability of a scale, which provides an indication of the internal consistency of the items evaluating the same construct (Hair et al., 1992). The Cronbach's alpha for all the constructs was found to exceed the standard suggested level of 0.70 (Hair et al., 1992; Nunnaly, 1978) except for apathy towards course material (0.667), which was found at the satisfactory level.

Table 2. Descriptive Statistics

\begin{tabular}{|l|c|c|c|c|c|}
\hline Construct & \# of Items & Mean & SD & CA $(\alpha)$ & Reliability Type \\
\hline Lack of Attention (LAN) & 3 & 2.13 & 0.75 & 0.774 & High \\
\hline Apathy towards Course Material (APT) & 3 & 2.22 & 0.65 & 0.667 & Moderate \\
\hline Distraction by Others (DST) & 3 & 2.94 & 0.93 & 0.811 & High \\
\hline Subjective Norm (SN) & 3 & 2.66 & 0.89 & 0.921 & Excellent \\
\hline Perceived Threat (PTH) & 3 & 3.17 & 0.82 & 0.789 & High \\
\hline Perceived Behavioral Control (PBC) & 3 & 3.23 & 0.87 & 0.808 & High \\
\hline Escapism (ESC) & 3 & 2.65 & 0.86 & 0.811 & High \\
\hline Attitude (ATD) & 2 & 2.66 & 0.84 & 0.748 & High \\
\hline Cyberslacking Intention (INT) & 3 & 2.88 & 0.91 & 0.839 & High \\
\hline
\end{tabular}

[Legend: SD: Standard Deviation, CA: Cronbach's Alpha $(\alpha)$ ]

\subsection{Measurement Model}

We tested the convergent and discriminant validity of the scales using confirmatory factor analysis (CFA) as part of the measurement model. The CFA showed that the selected items loaded favourably on their corresponding constructs and provided convincing empirical evidence of their validity. Similar to the Cronbach's alpha values, the composite reliability values were found to be greater than the expected minimum standard value of 0.70 (Hair et al., 1992; Nunnaly, 1978) for all the constructs except apathy towards course material (see 
Table 3). Average variance extracted (AVE) measures the deviation explained by the latent variable to random measurement error (Netemeyer et al., 1990) and ranged from 0.694 to 0.902 (except for apathy towards course materials whose AVE was found close to 0.50). It has been argued that AVE estimates of 0.45 or higher are acceptable indications of validity (Netemeyer et al., 2003; Rana and Dwivedi, 2015). The justification of retaining apathy towards course material as a construct in the proposed research model despite its relatively low reliability and AVE is largely due to its role and relevance in understanding the intentions of cyberslacking by students in the classroom environment. Further, the slightly lower value of CR and AVE for apathy towards course material does not affect the overall discriminant validity (Fornell and Larcker, 1981).

Table 3. Results of Confirmatory Factor Analysis

\begin{tabular}{|c|c|c|c|c|}
\hline Construct & Measure & SFL & $\mathrm{CR}$ & AVE \\
\hline \multirow[t]{3}{*}{ Lack of Attention (LAN) } & LAN1 & 0.59 & \multirow{3}{*}{0.795} & \multirow{3}{*}{0.694} \\
\hline & LAN2 & 0.83 & & \\
\hline & LAN3 & 0.82 & & \\
\hline \multirow[t]{3}{*}{ Apathy towards Course Material (APT) } & APT1 & 0.61 & \multirow{3}{*}{0.670} & \multirow{3}{*}{0.455} \\
\hline & APT2 & 0.73 & & \\
\hline & APT3 & 0.56 & & \\
\hline \multirow[t]{3}{*}{ Distraction by Others (DST) } & DST1 & 0.68 & \multirow{3}{*}{0.819} & \multirow{3}{*}{0.735} \\
\hline & DST2 & 0.88 & & \\
\hline & DST3 & 0.76 & & \\
\hline \multirow[t]{3}{*}{ Subjective Norm (SN) } & SN1 & 0.82 & \multirow{3}{*}{0.920} & \multirow{3}{*}{0.902} \\
\hline & SN2 & 0.93 & & \\
\hline & SN3 & 0.92 & & \\
\hline \multirow[t]{3}{*}{ Perceived Threat (PTH) } & PTH1 & 0.66 & \multirow{3}{*}{0.792} & \multirow{3}{*}{0.684} \\
\hline & PTH2 & 0.76 & & \\
\hline & PTH3 & 0.82 & & \\
\hline \multirow[t]{3}{*}{ Perceived Behavioral Control (PBC) } & $\mathrm{PBC1}$ & 0.68 & \multirow{3}{*}{0.812} & \multirow{3}{*}{0.721} \\
\hline & $\mathrm{PBC} 2$ & 0.84 & & \\
\hline & PBC3 & 0.78 & & \\
\hline \multirow[t]{3}{*}{ Escapism (ESC) } & ESC1 & 0.77 & \multirow{3}{*}{0.811} & \multirow{3}{*}{0.716} \\
\hline & ESC2 & 0.75 & & \\
\hline & ESC3 & 0.78 & & \\
\hline \multirow[t]{2}{*}{ Attitude (ATD) } & ATD1 & 0.87 & \multirow{2}{*}{0.833} & \multirow{2}{*}{0.782} \\
\hline & ATD2 & 0.82 & & \\
\hline \multirow[t]{3}{*}{ Cyberslacking Intention (INT) } & INT1 & 0.77 & \multirow{3}{*}{0.833} & \multirow{3}{*}{0.758} \\
\hline & INT2 & 0.76 & & \\
\hline & INT3 & 0.84 & & \\
\hline
\end{tabular}

Discriminant validity was evaluated using the test suggested by Anderson and Gerbing (1988). To comply to this test, the factor correlation between a pair of latent variables should be less than the square root of AVE, which are shown in bold font along the diagonal in Table 4. The test of validity showed that the square root of AVE for each variable was always larger than the correlation value for any pair of variables. For example, the correlation between LAN and APT is 0.324, which is less than the square root of AVE for both LAN (0.833) and APT (0.674) shown along the diagonal of the table. Explaining the discriminant validity in another way, Smith and Barclay (1997) argued that a variable could be considered different from other variables if its' square root of AVE is greater than its correlation with 
other latent variables. This condition was satisfied for every variable in Table 4. Therefore, we can argue that overall the requirements of convergent and discriminant validity for all scales are met.

Table 4. Factor Correlation Matrix

\begin{tabular}{|l|c|c|c|c|c|c|c|c|c|}
\hline Variable & LAN & APT & DST & SN & PTH & PBC & ESC & ATD & INT \\
\hline LAN & $\mathbf{0 . 8 3 3}$ & & & & & & & & \\
\hline APT & $0.324^{\mathrm{b}}$ & $\mathbf{0 . 6 7 4}$ & & & & & & & \\
\hline DST & 0.037 & -0.053 & $\mathbf{0 . 8 5 7}$ & & & & & & \\
\hline SN & $0.426^{\mathrm{b}}$ & 0.081 & 0.078 & $\mathbf{0 . 9 5 0}$ & & & & & \\
\hline PTH & $0.226^{\mathrm{b}}$ & 0.081 & $0.307^{\mathrm{b}}$ & $0.267^{\mathrm{b}}$ & $\mathbf{0 . 8 2 7}$ & & & & \\
\hline PBC & 0.077 & 0.022 & -0.119 & $0.174^{\mathrm{a}}$ & 0.043 & $\mathbf{0 . 8 4 9}$ & & & \\
\hline ESC & $0.505^{\mathrm{b}}$ & 0.121 & $0.211^{\mathrm{b}}$ & $0.316^{\mathrm{b}}$ & $0.215^{\mathrm{b}}$ & -0.025 & $\mathbf{0 . 8 4 6}$ & & \\
\hline ATD & $0.243^{\mathrm{b}}$ & $0.216^{\mathrm{b}}$ & $-0.191^{\mathrm{b}}$ & 0.143 & -0.072 & $0.244^{\mathrm{b}}$ & $0.154^{\mathrm{a}}$ & $\mathbf{0 . 8 8 4}$ & \\
\hline INT & $0.326^{\mathrm{b}}$ & $0.179^{\mathrm{a}}$ & $-0.201^{\mathrm{b}}$ & $0.312^{\mathrm{b}}$ & -0.093 & $0.319^{\mathrm{b}}$ & $0.254^{\mathrm{b}}$ & $0.481^{\mathrm{b}}$ & $\mathbf{0 . 8 7 1}$ \\
\hline
\end{tabular}

[Note: Square root of AVE in bold; ${ }^{\mathrm{a}}=\mathrm{p}<0.05 ;{ }^{\mathrm{b}}=\mathrm{p}<0.01$; blank $=\mathrm{p}>0.05$ ]

Key fit indices including normed Chi-Square (CMIN/DF), Adjusted Goodness of Fit Index (AGFI), Comparative Fit Index (CFI) and Root Mean Square Error of Approximation (RMSEA) have all been tested to evaluate model fit. Anderson and Gerbing (1988) found CFI as one of the most stable and strongest fit indices. We also report RMSEA, which analyses the discrepancy per degree of freedom. CFI should be greater than 0.90 (Hoyle, 1995) while AGFI should be greater than or equal to 0.80 (Chin and Todd, 1995) whereas RMSEA should be less than or equal to 0.06 to be considered indicative of good fit between the hypothesised model and observed data (Hu and Bentler, 1999). As shown in Table 5, the fit indices (CMIN/DF=1.33, AGFI=0.832, CFI=0.957, RMSEA=0.042) demonstrated a good measurement model (Anderson and Gerbing, 1988; Bagozzi and Yi, 1988).

Table 5. Model Fit Summary

\begin{tabular}{|c|c|c|c|}
\hline Fit Statistics & $\begin{array}{l}\text { Recommended } \\
\text { Value }\end{array}$ & $\begin{array}{l}\text { Measurement } \\
\text { model }\end{array}$ & Structural model \\
\hline Chi-Square $\left(\chi^{2}\right) /$ Degree of Freedom (DF) & $\leq 3.000$ & $382.76 / 288=1.33$ & $398.8 / 285=1.40$ \\
\hline Adjusted Goodness of Fit Index (AGFI) & $\geq 0.800$ & 0.832 & 0.830 \\
\hline Comparative Fit Index (CFI) & $\geq 0.900$ & 0.957 & 0.947 \\
\hline $\begin{array}{l}\text { Root Mean Square Error of Approximation } \\
\text { (RMSEA) }\end{array}$ & $\leq 0.060$ & 0.042 & 0.046 \\
\hline
\end{tabular}

\subsection{Structural Model}

Structural model testing examined the relationships between the latent variables using AMOS 22.0. The fit indices confirmed that the factor structure is an appropriate representation of the underlying data (CMIN/DF=1.40, AGFI=0.830, CFI=0.947, RMSEA=0.046) (Table 5). Having established the adequacy of the structural model fit, it was appropriate to examine the path coefficients of individual relationships as hypothesised in the proposed research model.

Table 6. Path Coefficients and Hypotheses Testing

\begin{tabular}{|l|l|c|c|c|c|}
\hline Hypothesis & Relationship & $\begin{array}{c}\text { Standardised } \\
\text { Regression Weight }\end{array}$ & $\begin{array}{c}\text { Critical } \\
\text { Ratio }\end{array}$ & $\begin{array}{c}\text { Significance } \\
(p)\end{array}$ & Supported \\
\hline H1 & LAN $\rightarrow$ ATD & $0.208^{*}$ & 2.346 & 0.019 & YES \\
\hline H2 & APT $\rightarrow$ ATD & $0.210^{*}$ & 2.093 & 0.036 & YES \\
\hline H3 & DST $\rightarrow$ ATD & $-0.253^{* *}$ & -3.043 & 0.002 & YES \\
\hline H4 & ATD $\rightarrow$ INT & $0.443^{* * *}$ & 5.382 & $<0.001$ & YES \\
\hline
\end{tabular}




\begin{tabular}{|l|l|c|c|c|c|}
\hline H5 & SN $\rightarrow$ INT & $0.225 * *$ & 2.985 & 0.003 & YES \\
\hline H6 & PTH $\rightarrow$ INT & $-0.209 * *$ & -2.822 & 0.005 & YES \\
\hline H7 & PBC $\rightarrow$ INT & $0.250 * *$ & 3.284 & 0.001 & YES \\
\hline H8 & ESC $\rightarrow$ INT & $0.219 * *$ & 2.654 & 0.008 & YES \\
\hline
\end{tabular}

Legend: $* \mathrm{p}<0.05, * * \mathrm{p}<0.01, * * * \mathrm{p}<0.001$

The results of hypotheses testing (Table 6) indicate that all eight relationships were supported by the data. While lack of attention (H1) and apathy towards course material (H2) were found to have a significant positive effect on attitude, distraction by others (H3) had a significant negative effect on attitude. Moreover, attitude was found to have the strongest and most significant impact on cyberslacking intention (H4). Subjective norm (H5), perceived behavioral control (H7) and escapism (H8) were also found to have a significant positive effect on cyberslacking intention. However, perceived threat had a significant negative influence on cyberslacking intention (H6). Figure 1 shows the validated research model with path coefficients and significance of each relationship. The validated model explained $18 \%$ of variance in attitude and $48 \%$ in students' cyberslacking intention.

\section{Discussion}

This research aimed to provide further understanding of the factors influencing students' cyberslacking attitude and intention in the classroom. Considering the first research question of this study, the results of quantitative data analysis through structural equation modelling showed that all eight hypotheses were supported. It is important to consider each in the context of existing research.

The results indicate that lack of attention positively influences students' attitude. It can be argued that lack of attention could be an outcome of lack of engagement in the class, which could lead to students' boredom and lower class participation. Lack of student engagement could be possible due to various reasons including complex course material, ineffective teaching methods and style of delivery, lack of students' background knowledge, and poor attitude, skills and habits. As a result, a student would be less likely to pay attention in the class and divert their attention towards activities like cyberslacking. On the other hand, if a student was willing to participate in the class activities and pay attention to the teaching, they might not get involved in cyberslacking even if they did it on previous occasions (Barry et al., 2015; Soh et al., 2018; Taneja et al., 2015). Because of the above-mentioned reasons, the student would form a positive attitude to cyberslacking in the classroom if they lack attention. Similarly, it could also be argued that apathy towards course material is one of the key reasons why students form favourable attitudes to non-class related activities such as cyberslacking. Given the ubiquity of Internet-enabled devices among students in British universities, they are an easy means of distraction for students disinterested with the teaching and learning due to various reasons, including apathy with course materials (Chan et al., 2009; Mathwick et al., 2001). The negative effect of distraction by others on cyberslacking attitude has also been supported by previous studies (e.g. Taneja et al., 2015). Feeling distracted by other students' cyberslacking behavior negatively affects attitudes of cyberslacking being good, fun and enjoyable. A study by Wallace et al. (2012) of attitude toward the use of mobile computing devices in medical education also supported this finding. 


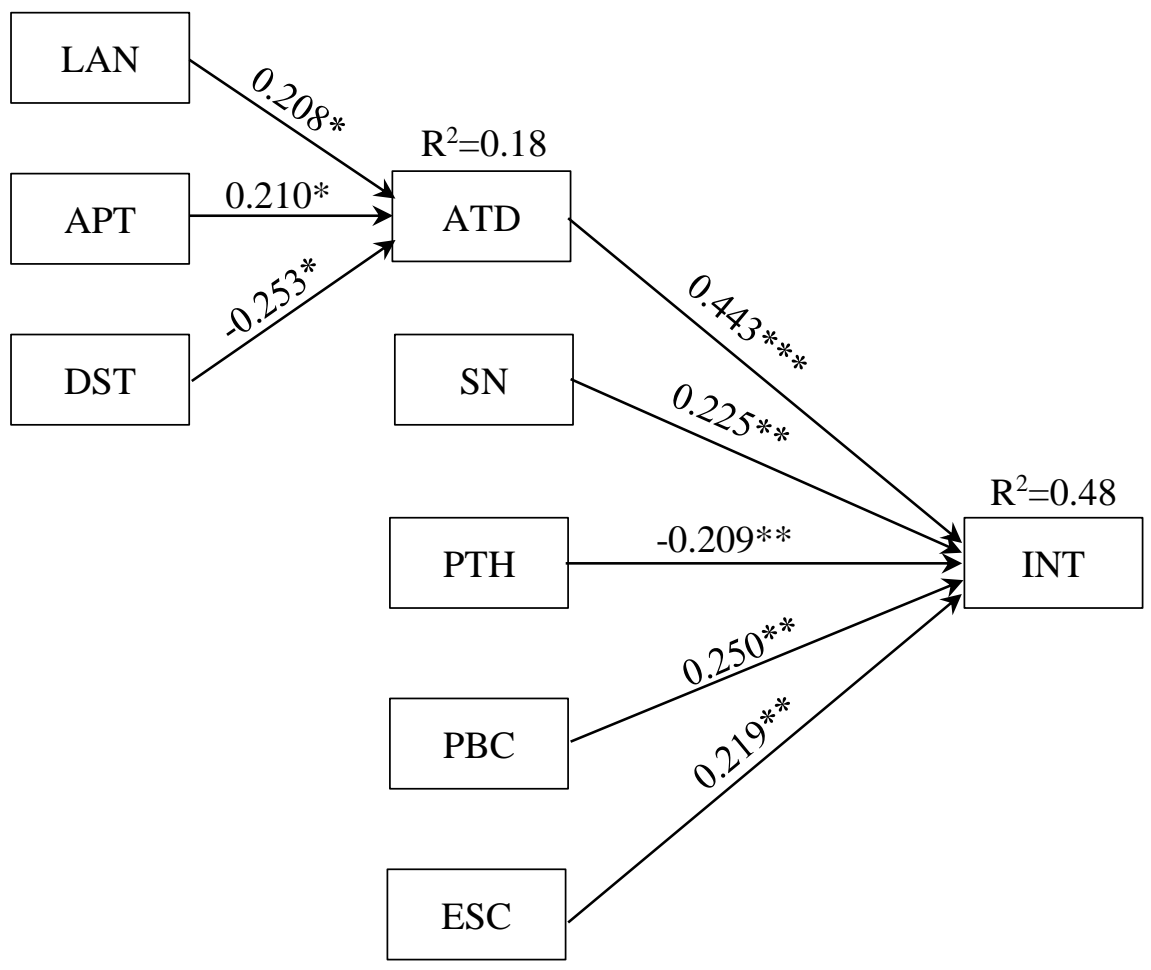

Figure 1. Validated research model (Adapted from Ajzen, 1991)

[Legend: APT: Apathy towards course material; ATD: Attitude; DST: Distraction by others; ESC: Escapism; INT: Cyberslacking intention; LAN: Lack of attention; PBC: Perceived behavioral control; PTH: Perceived Threat; SN: Subjective norm]

Considering the second research question, this study found attitude to have the largest effect on students' cyberslacking intention. Prior research (e.g. Liberman et al., 2011; Taneja et al., 2015) has shown that attitude toward cyberslacking does play a role in cyberslacking behavior. Consistent with TPB (Ajzen, 1991), other predictors such as SN and PBC were also found to have a positive and significant impact on cyberslacking intention. Based on these findings, we can infer that students' intentions to cyberslack are greater if they perceive expectations from their peers to do so. The positive impact of PBC on cyberslacking intention indicates that the easier the opportunity to cyberslack in the class, the greater the students' intention to perform such behavior (Gerow et al., 2010; Taneja et al., 2015). Greater opportunities to cyberslack result from the ubiquity of Internet-enabled devices among students. The negative effect of perceived threat on cyberslacking intention indicates that students' cyberslacking intentions are reduced if they perceive that the behavior will be penalised in some way. Lastly, the positive effect of escapism on cyberslacking intention indicates that the higher a student's desire to escape, the greater their intention to cyberslack (Griffiths, 2003; Mathwick et al., 2001). Therefore, cyberslacking is a means of escapism for students.

\subsection{Contributions to Research}

This research offers a number of contributions to academic literature on cyberslacking. Firstly, this research has performed a comprehensive review of empirical studies on cyberslacking and attempted to consolidate these. Secondly, this research has empirically tested an extended TPB model using additional constructs including lack of attention, apathy 
towards course material, and distraction from others as the predictors of attitude, and perceived threat and escapism as the antecedents of students' cyberslacking intentions. This combination of constructs has explained a good level of variance in cyberslacking intention $(48 \%)$ with relatively fewer and more impactful constructs compared to other studies. This is the most parsimonious model tested until now with such high variance on cyberslacking intention. Thirdly, the research has been undertaken using data gathered from students from a university in the UK. To the best of our understanding, this is the first empirical research of its type on cyberslacking in the UK higher education context. Therefore, this is a building block for future research about cyberslacking behavior in UK university classes. Moreover, the inclusion of additional constructs as antecedents of attitude (i.e. lack of attention, apathy towards course materials and distraction by others) and cyberslacking intention (i.e. perceived threat and escapism) established the significance of these variables in the cyberslacking context. Researchers could add these constructs to other technology adoption models to further explore students' cyberslacking intentions.

\subsection{Implications for Academics and Educators}

The positive effect of lack of attention and apathy towards course material on attitude, and escapism on cyberslacking intention, indicates that instructors should try their best to engage their students in the classroom to inhibit favourable attitudes towards cyberslacking and prevent cyberslacking intentions. Students can be engaged through interesting delivery of lectures, such as using clickers for triggering discussions, adding multimedia elements to presentations, introducing a game-based learning platform as an approach to difficult topics and subjects, and use of websites that host teacher-made video content, to name a few. Different approaches such as flipped-classroom and lectorials should be considered. As far as overcoming students' apathy towards course material is concerned, the instructor should make sure that courses are well designed and cross-checked by experienced instructor(s) in that subject area or those with programme-level oversight. While designing course material instructors should also make sure to avoid information overload on presentation slides, make explanations simple and easy to understand, provide helpful supplements during the lecture, avoid technical jargon, and update online courses to add recent developments in the area (Bhattacharya, 2017). Through reducing positive attitudes towards cyberslacking, instructors will also be directly reducing students' cyberslacking intentions. Prior research by Rana et al. (2016c) also supported the positive correlations between lack of attention and apathy towards course material with cyberslacking attitude.

There are a number of approaches that can be taken at a broader institutional level as well. The significant impact of subjective norm on cyberslacking intention indicates that the institution should attempt to reach out to students' families, student representatives or high performing fellow students, student experience officers, and role-model teachers to raise awareness of the downsides of, and distraction caused by, cyberslacking and encourage them to discuss these with students. The significant influence of perceived threat on cyberslacking intention also indicates that there could be some benefit in the institution imposing sanctions for cyberslacking behavior, such as grade penalties. Clear guidelines for the module and educational policies for the institution at large should clearly indicate the line of punishment for using smartphones for non-class related activities (Taneja et al., 2015). As a result of such policies, students may also perceive there to be more difficulty to participate in cyberslacking behavior, which will also help to lower intentions, according to the findings aforementioned. 


\subsection{Contributions for Technology Enhanced Learning in Higher Education}

The use of technology to optimise the student learning experience is a key area of interest across researchers in the Higher Education sector. Technology enhanced learning can be used to refer to electronic learning and learning with technology, rather than learning just through technology (Higher Education Academy, 2018). This research has a significant contribution for technology enhanced learning in Higher Education. This research indicates how in an attempt to escape what is going on in class, students may resort to cyberslacking. Engaging students with their devices as part of the class activity may help to prevent mis-use of the technology. However, the findings of the research also reveal that innovative instructors who attempt to utilise new technologies in class to encourage student engagement must have good control of their class and keep monitoring activities, so as not to inadvertently facilitate the forming of favourable attitudes towards cyberslacking. Instructors should not be afraid to call out students who consistently engage in inappropriate activities through their devices. In this regard, institutions should also formulate clear guidelines and policies on the use of technology for class-related purposes.

\section{Conclusions}

In this research, we attempted to understand the motivations behind students' intentions to engage in cyberslacking behavior. For this, TPB was used as a basic research model to which additional constructs were added including lack of attention, apathy towards course material, and distraction from others as antecedents of attitude, and perceived threat and escapism as antecedents of cyberslacking intention. Data were collected $(n=188)$ from management students in a British university and support was found for all eight hypotheses. The validated research model depicts factors affecting students' cyberslacking intentions. Based on the findings, we have provided suggestions for instructors and institutions about methods they can adopt to minimise students' cyberslacking intentions.

\subsection{Limitations and Future Research}

Like other research, this research is not without limitations. Firstly, as the data related to various factors have been gathered from undergraduate and postgraduate students at a UK University, it would be difficult to generalise the results and apply the findings to any other context. Future researchers should take caution while replicating this model to understand the factors influencing cyberslacking intentions to other contexts such as universities from different countries, cultures, and disciplines. Furthermore, researchers could explore some more relevant factors in diverse settings in such a way that a holistic policy could be formulated for any educational institutions consisting of various disciplines. Secondly, this study did not measure cyberslacking behavior. It would be beneficial if actual behavior could be observed in a future study. Thirdly, this study has used a sample of 188 students only. Future research could use a larger sample of students to validate the proposed research model. Thirdly, this research has used a sample of students only from the management discipline, thus further studies could understand students from other disciplines such as Arts, Science, and Engineering to understand such students' cyberslacking intentions. Finally, respondents' personal profile data (except demographic profile) such as individual traits, learning style, knowledge, interests, goals, background, and acceptance of technology were 
not analysed. Future research can collect more detailed personal profile data about respondents.

\section{References}

Aghaz, A., \& Sheikh, A. (2016). Cyberloafing and job burnout: An investigation in the knowledge-intensive sector. Computers in Human Behavior, 62, 51-60.

Ajzen, I. (1991). The Theory of Planned Behavior. Organizational Behavior and Human Decision Processes, 50(2), 179-211.

Akbulut, Y., Dönmez, O., \& Dursun, Ö. Ö. (2017). Cyberloafing and social desirability bias among students and employees. Computers in Human Behavior, 72, 87-95.

Akbulut, Y., Dursun, Ö. Ö., Dönmez, O., \& Şahin, Y. L. (2016). In search of a measure to investigate cyberloafing in educational settings. Computers in Human Behavior, 55, 616-625.

Anderson, J. C., and Gerbing, D. W. (1988). Structural Equation Modeling in practice: A review and recommended two-step approach. Psychological Bulletin, 103(3), 411-423.

Askew, K., Buckner, J. E., Taing, M. U., Ilie, A., Bauer, J. A., \& Coovert, M. D. (2014). Explaining cyberloafing: The role of the Theory of Planned Behavior. Computers in Human Behavior, 36, 510-519.

Bagozzi, R. P., \& Yi, Y. (1988). On the evaluation of structure equation models. Journal of the Academy of Marketing Science, 16(1), 74-94.

Barry, S., Murphy, K., \& Drew, S. (2015). From deconstructive misalignment to constructive alignment: Exploring student uses of mobile technologies in university classrooms. Computers \& Education, 81, 202-210.

Baturay, M. H., \& Toker, S. (2015). An investigation of the impact of demographics on cyberloafing from an educational setting angle. Computers in Human Behavior, 50, 358-366.

Bhattacharya, P. (2017). 7 Features of the ideal online course to prevent drop outs. ELearning Industry. Accessed from https://elearningindustry.com/ideal-online-course-preventdrop-outs on 27th September 2018.

Chan, C. K., So, W. K., \& Fong, D. Y. (2009). Hong Kong baccalaureate nursing students' stress and their coping strategies in clinical practice. Journal of Professional Nursing, 25, 307-313.

Chin, W. W., \& Todd, P.A. (1995). On the use, usefulness, and ease of use of structural equation modeling in MIS research: A note of caution. MIS Quarterly, 19(2), 237-246.

Davis F. D., Bagozzi R. P., \& Warshaw, P. R. (1989). User acceptance of computer technology: A comparison of two theoretical models. Management Science, 35(8), 982-1002.

Deed, C. (2011). Accessing students' reasoning for disengagement. International Journal on School Disaffection, 8(2), 24-28.

Dwivedi, Y.K., Rana, N.P., and Janssen, M., Lal, B., Williams, M.D., \& Clement, M. (2017a). An Empirical Validation of a Unified Model of Electronic Government Adoption (UMEGA). Government Information Quarterly, 34(2), 211-230.

Dwivedi, Y. K., Rana, N. P., Jeyaraj, A., Clement, M., \& Williams, M. D. (2017b). Reexamining the unified theory of acceptance and use of technology (UTAUT): Towards a revised theoretical model. Information Systems Frontiers, 1-16, DOI: 10.1007/s10796-0179774-y. 
Fishbein, M., \& Ajzen, I. (1975). Belief, Attitude, Intention and Behavior: An Introduction to Theory and Research. Reading, MA: Addison-Wesley.

Fornell, C., \& Larcker, D. F. (1981). Evaluating structural equation models with unobservable variables and measurement error. Journal of Marketing Research, 18(1), 39-50.

Fried, C. B. (2008). In-class laptop use and its effects on student learning. Computers \& Education, 50, 906-914.

Galluch, P. S., \& Thatcher, J. B. (2006). Slacking and the internet in the classroom: A preliminary investigation. SIGHCI 2006 Proceedings, 12.

Galluch, P., \& Thatcher, J. (2011). Maladaptive vs. faithful use of internet applications in the Classroom: An empirical examination. Journal of Information Technology Theory and Application, 12(1), 5-21.

Gerow, J. E., Galluch, P. S., \& Thatcher, J. B. (2010). To slack or not to slack: Internet usage in the classroom. Journal of Information Technology Theory and Application, 11(3), 5-24.

Giunchiglia, F., Zeni, M., Gobbi, E., Bignotti, E., \& Bison, I. (2018). Mobile social media usage and academic performance. Computers in Human Behavior, 82, 177-185.

Gokcearslan, S., Mumcu, F. K., Haslaman, T., \& Cevik, Y. D. (2016). Modelling smartphone addiction: The role of smartphone usage, self-regulation, general self-efficacy and cyberloafing in university students. Computers in Human Behavior, 63, 639-649.

Griffiths, M. (2003). Internet abuse in the workplace: Issues and concerns for employers and employment counselors. Journal of Employment Counseling, 40, 87-96.

Hair, J. F., Anderson, R. E., Tatham, R. L. \& Black, W. C. (1992). Multivariate Data Analysis with Readings. 3rd Edition. New York, NY: Macmillan Publishing Company.

Higher Education Academy (2018). Technology enhanced learning. Advanced HE. Accessed from https://www.heacademy.ac.uk/individuals/strategic-priorities/technology-enhanced-learning on 7 th March 2019.

Higher Education Statistics Agency (2019). Who's studying in HE? Accessed from https://www.hesa.ac.uk/data-and-analysis/students/whos-in-he on 10th March 2019.

Hoyle, R. H. (1995). The Structural Equation Modeling Approach: Basic Concepts and Fundamental Issues. Thousand Oaks, CA: Sage Publications.

Hu, L.-T., \& Bentler, P. M. (1999). Cutoff criteria for fit indexes in covariance structure analysis: Conventional criteria versus new alternatives. Structural Equation Modeling, 6, 155 .

Ince, M., \& Gul, H. (2011). The relation of cyber slacking behaviors with various organizational outputs: Example of Karamanoğlu Mehmetbey University. European Journal of Scientific Research, 52(4), 507-527.

Keser, H., Kavuk, M., \& Numanoglu, G. (2016). The relationship between cyber-loafing and internet addiction. Cypriot Journal of Educational Sciences, 11(1), 37-42.

Liberman, B., Seidman, G., Mckenna, K. Y., \& Buffardi, L. E. (2011). Employee job attitudes and organizational characteristics as predictors of cyberloafing. Computers in Human Behavior, 27(6), 2192-2199.

Mathwick, C., Malhotra, N., \& Rigdon, E. (2001). Experiential value: Conceptualization, measurement and application in the catalog and Internet shopping environment. Journal of Retailing, 77, 39-56. 
McBride, J., Milligan, J., \& Nichols, J. (2013). "Cyberslacking" in the classroom: the reactions of classroom teachers. College Student Journal, 47(1), 212-218.

Mendoza, J. S., Pody, B. C., Lee, S., Kim, M., \& McDonough, I. M. (2018). The effect of cellphones on attention and learning: The influences of time, distraction, and nomophobia. Computers in Human Behavior, 86, 52-60.

Montano, D. E., \& Kasprzyk, D. (2015). Theory of Reasoned Action, Theory of Planned Behavior, and the Integrated Behavioral Model. In Glanz, K., Rimer, B., \& Viswanath, K. (eds.) Health Behavior: Theory, Research and Practice. $5^{\text {th }}$ Edition. San Francisco (CA): Jossey-Bass.

Netemeyer, R. G., Bearden, W. O., \& Sharma, S. (2003). Scaling procedures: Issues and applications. Thousand Oaks, CA: Sage Publications.

Netemeyer, R.G., Johnston, M.W., \& Burton, S. (1990). Analysis of role conflict and role ambiguity in a structural equations framework. Journal of Applied Psychology, 75(2), 148157.

Nunnaly, J. (1978). Psychometric theory. New York: McGraw-Hill.

O’Neill, T. A., Hambley, L. A., \& Bercovich, A. (2014). Prediction of cyberslacking when employees are working away from the office. Computers in Human Behavior, 34, 291-298.

Ragan, E. D., Jennings, S. R., Massey, J. D., \& Doolittle, P. E. (2014). Unregulated use of laptops over time in large lecture classes. Computers \& Education, 78, 78-86.

Rana, N. P., \& Dwivedi, Y. K. (2015). Citizen's adoption of an e-government system: Validating extended social cognitive theory (SCT). Government Information Quarterly, $32(2), 172-181$.

Rana, N.P., Lal, B., and Slade, E. (2016a). Adoption of Two Indian E-Government Systems: Validation of Extended Theory of Planned Behavior (TPB). Americas Conference on Information Systems, San Diego, USA, 2016.

Rana, N.P., Dwivedi, Y.K., Lal, B., Williams, M.D., \& Clement, M. (2017). Citizens' Adoption of an Electronic Government System: Toward a Unified View. Information Systems Frontiers, 19(3), 549-568.

Rana, N.P., Dwivedi, Y.K., Williams, M.D., \& Weerakkody, V. (2016b). Adoption of Online Public Grievance Redressal System in India: Toward Developing a Unified View. Computers in Human Behavior, 59, 265-282.

Rana, N., Dwivedi, Y., Slade, E., \& Lal, B. (2016c). Cyber-slacking: Exploring students' usage of internet-enabled devices for non-class related activities. AMCIS 2016, San Diego, USA.

Ravizza, S. M., Hambrick, D. Z., \& Fenn, K. M. (2014). Non-academic internet use in the classroom is negatively related to classroom learning regardless of intellectual ability. Computers \& Education, 78, 109-114.

Samson, P. J. (2010). Deliberate engagement of laptops in large lecture classes to improve attentiveness and engagement. Computers in Education, 1(2), 1-19.

Sana, F., Weston, T., \& Cepeda, N. J. (2013). Laptop multitasking hinders classroom learning for both users and nearby peers. Computers \& Education, 62, 24-31.

Sharma, S. K., Joshi, A., \& Sharma, H. (2016). A multi-analytical approach to predict the Facebook usage in higher education. Computers in Human Behavior, 55, 340-353. 
Shiau, W. L., \& Chau, P. Y. (2016). Understanding behavioral intention to use a cloud computing classroom: A multiple model comparison approach. Information \& Management, 53(3), 355-365.

Smith, J. B., \& Barclay, D. W. (1997). The effects of organizational differences and trust on the effectiveness of selling partner relationships. Journal of Marketing, 61, 3-21.

Soh, P. C. H., Koay, K. Y., \& Lim, V. K. (2018). Understanding cyberloafing by students through the lens of an extended Theory of Planned Behavior. First Monday, 23(6), 1-28.

Taneja, A., Fiore, V., \& Fischer, B. (2015). Cyber-slacking in the classroom: Potential for digital distraction in the new age. Computers \& Education, 82, 141-151.

Taylor, S., \& Todd, P. A. (1995a). Understanding information technology usage: A test of competing models. Information Systems Research, 6(2), 144-176.

Ugrin, J. C., \& Pearson, J. M. (2013). The effects of sanctions and stigmas on cyberloafing. Computers in Human Behavior, 29(3), 812-820.

Venkatesh, V., Morris, M. G., Davis, G. B., \& Davis, F. D. (2003). User acceptance of information technology: Toward a unified view. MIS Quarterly, 27(3), pp. 425-478.

Vitak, J., Crouse, J., \& LaRose, R. (2011). Personal Internet use at work: Understanding cyberslacking. Computers in Human Behavior, 27(5), 1751-1759.

Wallace, S., Clark, M., \& White, J. (2012). 'It's on my iPhone': Attitudes to the use of mobile computing devices in medical education, a mixed-methods study. BMJ Open, 2(4), 1-7.

Wu, J., Mei, W., \& Ugrin, J. C. (2018). Student cyberloafing in and out of the classroom in China and the relationship with student performance. Cyberpsychology, Behavior, and Social Networking, 21(3), 199-204.

Yasar, S., \& Yurdugul, H. (2013). The investigation of relation between cyberloafing activities and cyberloafing behaviors in higher education. Procedia-Social and Behavioral Sciences, 83, 600-604.

Yilmaz, F. G. K., Yilmaz, R., Ozturk, H. T., Sezer, B., \& Karademir, T. (2015). Cyberloafing as a barrier to the successful integration of information and communication technologies into teaching and learning environments. Computers in Human Behavior, 45, 290-298.

Y1lmaz, R., \& Yurdugul, H. (2018). Cyberloafing in IT classrooms: exploring the role of the psycho-social environment in the classroom, attitude to computers and computing courses, motivation and learning strategies. Journal of Computing in Higher Education, 30(3), 530552.

\section{Appendix - Survey Questionnaire}

The questions were using a Likert scale of 1-5 where 1 represents 'strongly disagree', 2 'disagree', 3 'undecided', 4 'agree', and 5 'strongly agree'.

APT1. I do not get along with the material discussed in the class

APT2. I am not interested in the topics being discussed in the class

APT3. I have trouble understanding the topics being discussed in the class

ATD1. Using the Internet or cell phone in class for non-class related purposes is fun

ATD2. Using the Internet or cell phone in class for non-class related purposes is enjoyable

ATD3. Using the Internet or cell phone in class for non-class related purposes is good

DST1. I am distracted when students around me use the Internet/cell phone for non-class related purposes 
DST2. My attention is diverted from the instructor if other people are using the Internet/cell phone for non-class related purposes

DST3. I lose concentration when students around me use the Internet/cell phone for non-class related purpose

ESC1. I use the Internet/cell phone for non-class related purpose in class because it helps to get away from what we are doing in class

ESC2. I use the Internet/cell phone for non-class related purpose in class because it helps to forget about school and other things

ESC3. I use the Internet/cell phone for non-class related purpose in class because it helps to divert attention from what's going in the class

INT1. I plan to use the Internet/cell phone for non-class related purposes during class in the future

INT2. I think I will likely use the Internet/cell phone to do something other than class-related activities during class in the future

INT3. I intend to use the Internet/cell phone for non-class related purpose during class in the future

LAN1. I usually don't pay attention in the class

LAN2. I don't usually care much about the course in the class

LAN3. I don't think it is worth paying attention to course

PBC1. Using Internet/cell phone for non-class related purposes is entirely up to me

PBC2. If I want to, I can use the Internet/cell phone for non-class related purposes

PBC3. If I choose to, I can use the Internet/cell phone for non-class related purposes

PTH1. If I slack with the Internet/cell phone in class, something bad will happen

PTH2. I perceive a threat from slacking with the Internet/cell phone

PTH3. Penalties will be imposed for slacking using the Internet/cell phone

SN1. My friends would think that I should use the Internet/cell phone in class for non-class related purposes

SN2. My classmates would think that I should use the Internet/cell phone in class for non-class related purposes

SN3. People sitting next to me in class would think that I should use the Internet/cell phone in class for non-class related purposes

APT: Apathy towards course material [Taneja et al., 2015]; ATD: Attitude [Taneja et al., 2015]; DST: Distraction by others [Taneja et al., 2015]; ESC: Escapism [Taneja et al., 2015]; INT: Intention to cyberslack [Gerow et al., 2010; Taneja et al., 2015]; LAN: Lack of attention [Taneja et al., 2015]; PBC: Perceived behavioral control [Taneja et al., 2015]; PTH: Perceived Threat [Galluch and Thatcher, 2011]; SN: Subjective norm [Taneja et al., 2015] 